\title{
電子機器冷却設計のための空冷ファンモデル
}

\section{Cooling fan model for the cooling design of electronic equipment}

\author{
○学 後藤真司（北大院） 正 池川昌弘（北大院） \\ Shinji GOTO, and Masahiro IKEGAWA \\ Hokkaido University, North 13, West8,Kita-ku,Sapporo,Hokkaido
}

\begin{abstract}
It is vital to calculate the flow rate when a cooling fan is applied to a cooling design of an electronic equipment. Usually, the flow rate is calculated by comparing a P-Q curve with a static pressure difference between front and back side of the fan. However, it is difficult to determine which location should be selected as the pressure evaluation point in a densely packed condition since the pressure field is not uniform. Thus, the accurate flow rate can not be determined through the conventional method. The objective of this study is to develop a cooling fan model that can be effectively employed for cooling design of electronic equipment.
\end{abstract}

Key Words: Fan Flow Rate, Axial Fan, Densely Packed Condition, Cooling Fan Model, P-Qcurve

1. 緒言

空阾ファンによる放熱設計を行ら際にはファン風量を知る必要があ る. 現在の推定方法はファン入口圧力と出口圧力である大気圧との静 圧差を求め, ファンメーカーによって供給される $\mathrm{P}-\mathrm{Q}$ 性能曲線との比

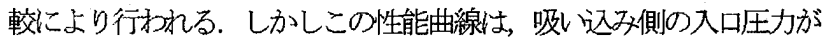
均一なチャンバーを用いて求められているため, ファンへの空気流入 は一様であるといら条件下で測定されている。 ノ一ト型PCに代表さ れる高密度実装 PC の内部では，装置や基板为密集しているため筀体 内部の圧力分布に大きな差方生じ，ファンへの空気流入が不均一にな っている(1)。このような場合，ファン入口部の参照圧力をどこで評価 するかが問題となる上に，ファンに近接して装置や基板か設置される 状況下ではP-Q 性能曲線そのものか変化し, ファン風量を正確に評価 することができない．

この問題の解決策の一つとして，当研究室では空冷ファンモデルの 構筑を行っている.このモデルは, ファンの送風作用を空気に対する 体積力上して取り扱い，解析モデルに組み込むといらものである. 今 回，ファンモデルの構築とモデルの検証とを目的として，ファン前方 に障害物を設置した場合の実験を行い，ファンモデルの評価を行った のでその結果を報告する.

\section{2. 実験装置及し実験办法}

図 lに実験装置図を示す。装置はアクリル製で，チャンバーの片側 にファン它設置した．高密度実装状態を模擬するた如に，ファンの前 面に距離dを介して障害物定設置する.

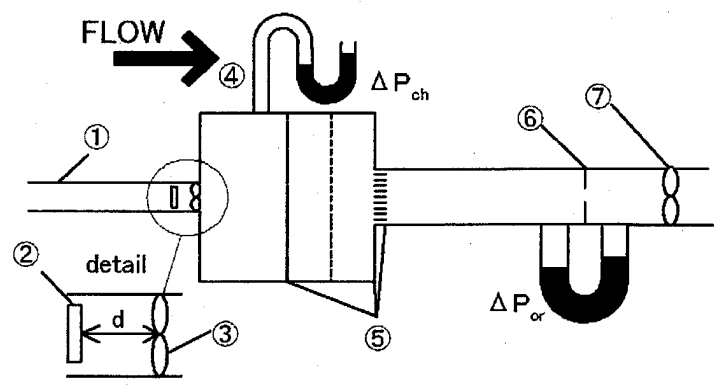
(1) duct
(2) obstacle (3) fan (4) chamber
(5) rectifier
(6) orifice (7) auxiliary fan

Fig.1 Experimental setup
距離 $\mathrm{d}$ は $5 \mathrm{~mm}, 10 \mathrm{~mm}, 20 \mathrm{~mm}, 30 \mathrm{~mm}$ の 4 パターンとした。障 害物には $30 \mathrm{~mm}$ 角, $25 \mathrm{~mm}$ 角, 厚さ $5 \mathrm{~mm}$ のアクリル製の正方形板 のものを用いた.このときファンとファン前方が $35 \mathrm{~mm}$ 角のダクト て用まれている場合とオープンな状況においての実験を行った。

実験装置のオリフィスの下流に補助ファンを取り付け, ファン吹出 部のチャンバー内の静圧が制御できるようになっている. チャンバー の圧力を大気圧に維持し，上記に述べた障害物の大きさとファンとの 跳離dのそれぞれの状況について風量を測定した.オリフィス前後の 差压測定は金属製のタップを差し込み, 微差压計 $(\mathrm{PZ}-77$, 精度 は土0.02Pa）を用いて測定した。

ファンモデルの評価を行うために，実験にはP-Q性能曲線の大きく 異なる2つのタイプのファンを用いた. 締切圧力は小さいが開放風量 の大きい軸方向に吹き出すタイプのファンA 開放風量の小さい横方向に吹き出すタイプのファンBである. (2)

3. ファンモデル

図2に示すようなファンを通過する流れを想定し，ファン仕事によ る静圧上昇を体積力 $\mathrm{f}$ て置換することを考える.

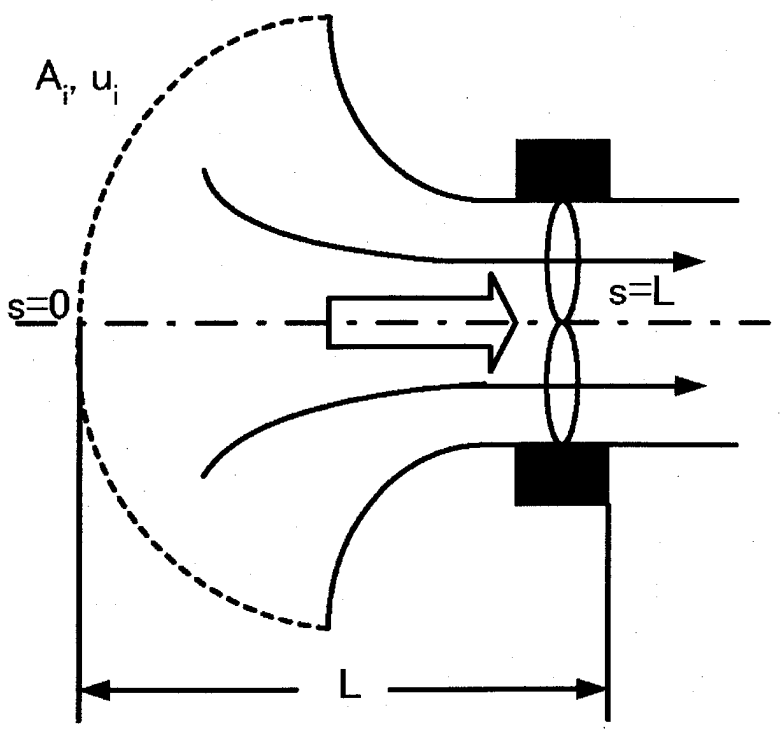

Fig2 Fan Model 
ファンを通過する流れに対する支配方程式は，粘性を無視しうる場 合には次のように与えられる。

$$
\rho u \frac{d u}{d s}=-\frac{\partial p^{*}}{\partial s}+f
$$

ここでs は流線に沿り座標であり， p*はファン仕事による圧力場を除 いた圧力場である。

ファン部分での圧力損失を考慮しファン領域で空気流速の 2 乗に比 例する抵抗を式（1）に付与すると

$$
\rho u \frac{d u}{d s}=-\frac{\partial p^{*}}{\partial s}+f-c u^{2}
$$

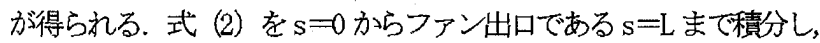
$\mathrm{s}=\mathrm{L}$ における圧力基淮现力 0 とすると

$$
\frac{P}{\Delta l}+f=c u^{2}+\rho \frac{u^{2}}{2 \Delta l}
$$

となる.ここに $\mathrm{P}$ は $\mathrm{s}=0$ にお访る圧力であり，通常負の值である. ま

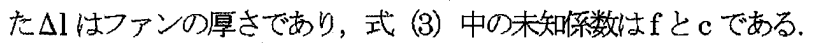

式 (3) に $\mathrm{P}-\mathrm{Q}$ 曲線上の2 点 $\left(\mathrm{P}, \mathrm{u}_{1}\right) ，\left(\mathrm{P}_{2}, \mathrm{u}_{2}\right)$ を代入することによ ってfとcの值求めると

$$
\begin{aligned}
& f=\frac{1}{2 \Delta l}\left\{\frac{\left(u_{1}^{2}+u_{2}^{2}\right)}{\left(u_{1}^{2}-u_{2}^{2}\right)}\left(P_{2}-P_{1}\right)+P_{1}+P_{2}\right\} \\
& c=\frac{1}{\Delta l} \frac{\left(P_{2}-P_{1}\right)}{\left(u_{1}^{2}-u_{2}^{2}\right)}-\frac{\rho}{2 \Delta l}
\end{aligned}
$$

が得られる。

\section{4. 実験結果, 解析結果および考察}

ファンとファン前方がダクトに囲まれていないオープンな状况につ

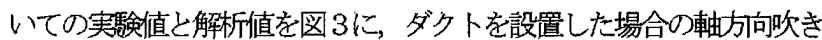
出しファンA，横方向吹き出しファンB の実験值と解析值の結果をそ れどれ図 4, 図5に示す，実験はいずれもファンの開放状態での実験 であるが，軸方向吹き出しファンは障害物の位置や大きさに風量が大 きく影響を受けているのがわかる. 一方で, 横方向吹き出しファンの 場合は風量はあまり変化していない：これは横方向吹き出しファンで は流入した空気の進行方向が 90 度変化させられることによる圧力損 失が大きいため，障害物の介在による圧力損失の割合が小さくなり， 障害物の大きさや位置に関してあまり影響を受けないためである.

これらを検証データとして電子機器冷却殷計シミミレレーションのた めの空泠ファンモデルの検討を行った.

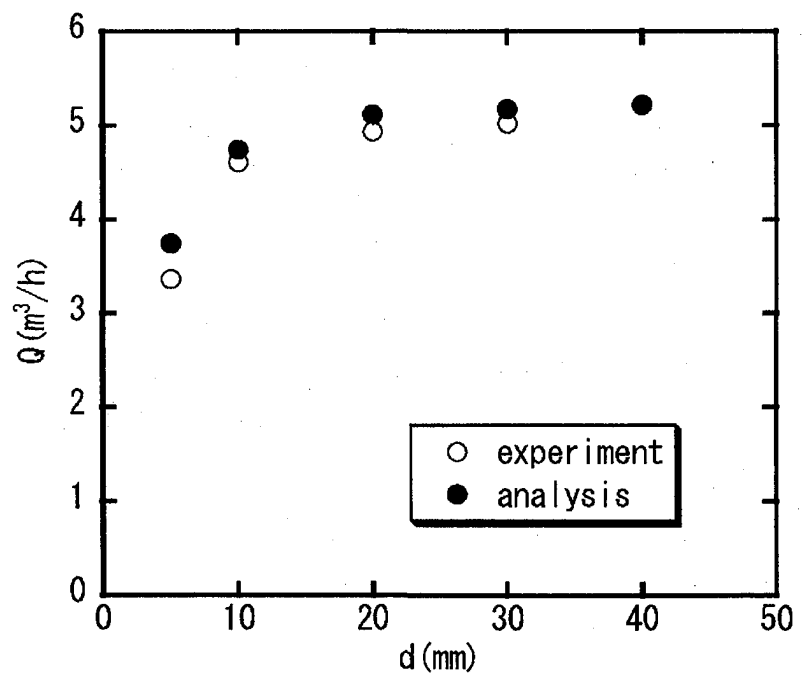

Fig.3 result of axial fan A set up in an open space

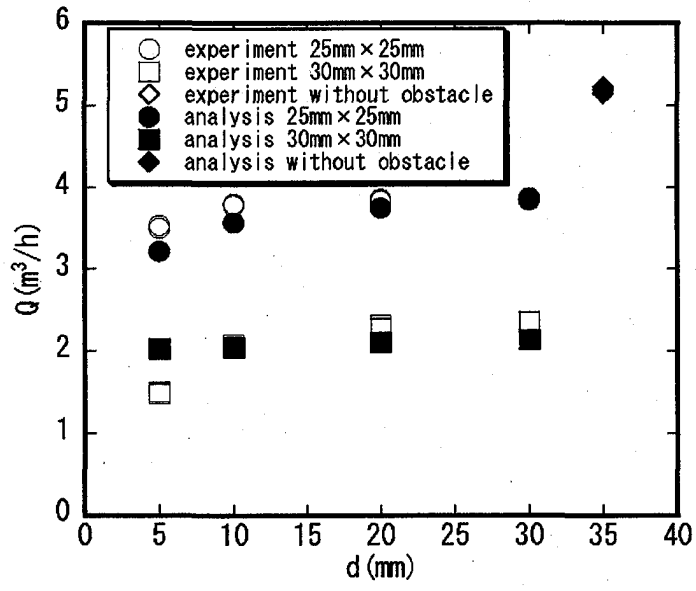

Fig.4 result of axial fan A set up in a duct

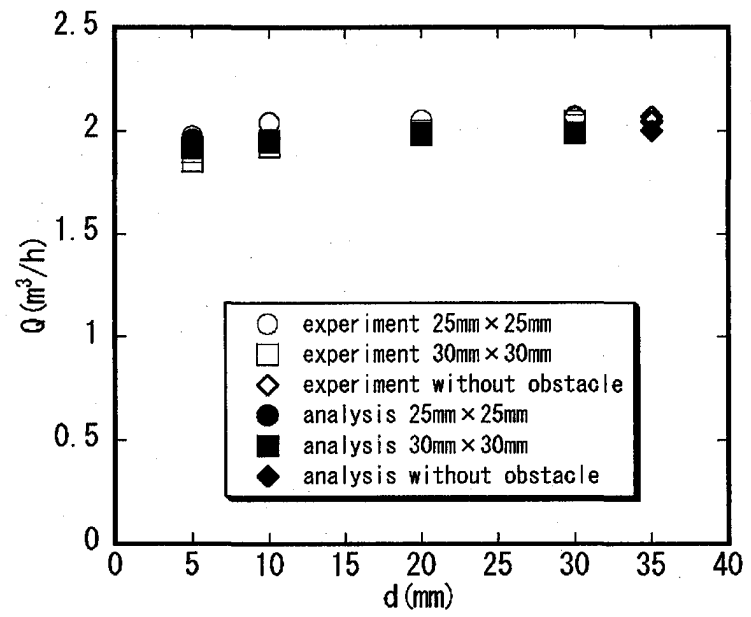

Fig.5 result of axial fan B set up in a duct

解析結果恃横方向吹き出しファンにおいては障害物の大きさに関わ らず，全体的に実験結果を再現できている. 軸方向欦き出しファンで も全体的に実験結果を再現できており，コンピュータによる泠却設計 を行う際こ組み込文得る可能性を持っていることがかかる。 しかし実 験值との誝差が大きくなっている部分も見受けられ，ファンモデルは 改良を要する部分があると言える。

今後, ファンモデル検証用のデータを増やし，さまざまな状况下で の槌咦験による評価とモデルの改良を行う予定である。

4. 結言

今回行った研究の範囲で以下の結論を得た。

（1）提唱したファンモデルは障嗐物とファンが近接した場合に誤差 が大きくなることがあるためモデルの改良を要する部分もある が，コンピュータによる冷却段計を行う際のファンモデルとし て組み込み得る可能性がある。

（2）検証用のデータを増やし，追加実験との比較検討によるモデル の検証と改良が必要である。

5. 参考文献

(1) 2004 年日本機械学会「RC202電子デバイス/電子実装に お引ける信頼性に関する研究分科会 研究報告書」資料

（2）池川昌弘，高橋大我他，コンパクトPC 用泠却ファンの性能泙 価，熱工学コンファレンス講演論文集，p 113 -114（20 03 年) 